\title{
Effect of pulp and paper mill effluent (BKME) on physiological parameters of roach (Rutilus rutilus) infected by the digenean Rhipidocotyle fennica
}

\author{
Zsigmond Jeney $^{1}$, E. Tellervo Valtonen ${ }^{2}$, Galina Jeney $^{1}$ and E. Ilmari Jokinen ${ }^{2}$ \\ ${ }^{1}$ Fish Culture Research Institute, P.O. Box 47, H-5541 Szarvas, Hungary; \\ ${ }^{2}$ University of Jyväskylä, Department of Biological and Environmental Science, P.O. Box 35, FIN-40351 Jyväskylä, Finland
}

Key words: BKME, Rhipidocotyle, parasite infection, fish physiology

\begin{abstract}
Physiological parameters were measured after experimental infection of roach (Rutilus rutilus L.) with Rhipidocotyle fennica Gibson, Valtonen et Taskinen, 1992 (Digenea) cercariae. The fish were caught from two lakes: a eutrophic bleached kraft mill effluent (BKME)-contaminated lake and an oligotrophic unpolluted lake. The intensity of infection was followed up to 10 days post infection (p.i.) and physiological parameters indicating non-specific stress responses and the condition of fish were examined simultaneously. The mean abundance, the number of parasites per fish, of $R$. fennica was significantly higher in the fish from the contaminated water during the first two days p.i., probably reflecting the decreased resistance of these fish to infection. The decrease of leukocrit, as well as the increase of the activity of transaminases (GOT and GPT) in infected fish of both groups are suggestive of pathological processes caused by cercariae penetrating the fish. A significantly lower leukocrit value, as well as higher alkaline phosphatase activity and plasma chloride levels were noted in fish originating from the contaminated lake compared to those from the unpolluted lake. No significant differences were noted in haematocrit, plasma protein and calcium values between the fish from the uncontaminated and contaminated lakes, or between the infected and uninfected control fish.
\end{abstract}

Chlorophenols, fatty acids and resin acids are the main acutely toxic and bioaccumulating compounds in bleached kraft mill effluents (BKME). Resin acids, like dehydroabietic acid, are released in both chemical and mechanical pulping (Oikari and Holmbom 1986, Granberg 1992). Inorganic nutrients from debarking cause eutrophication and organic compounds are also released, such as sugars and lignins which increase the biological oxygen demand load (Pajula and Matinvesi 1984). BKME has a wide range of effects in fish living in contaminated water areas. Typical symptoms in fish include reduced gonad growth, delayed maturity, liver enlargement, enhanced growth and strong induction of hepatic cytochrome P-450 dependent EROD (7-ethoxyresorufin O-deethylase) activity in addition to fin erosion and operculum deformities (reviewed by Tana and Lehtinen 1996). The immunological response of roach is impaired also due to BKME. Jokinen et al. (1995) found that serum immunoglobulin levels decreased significantly in two months in roach transferred to the contaminated Lake Vatia when compared to the fish kept in unpolluted Lake Peurunka. In addition, in immunised roach, the antibody secreting cell response was lower and antibody titres increased more slowly in the exposed fish indicating a weakened response to the antigen after subchronic exposure of roach to BKME. Jeney et al. (1996) found decreased lymphocyte numbers in blood of roach collected from contaminated Lake Vatia when compared with roach from uncon- taminated Lake Peurunka. In Central Finland a massinfection with larvae of the digenean trematode, Rhipidocotyle fennica Gibson, Valtonen et Taskinen, 1992, was observed mainly in the fins of roach in two eutrophic lakes downstream of the contaminated lake, where the effluent was already diluted significantly (Granberg 1992), but not in the contaminated lake due to absence of Anodonta piscinalis, the molluscan intermediate host of $R$. fennica (Valtonen et al. 1997).

Our aim was to investigate whether the fish from Lake Vatia, contaminated with BKME, are more susceptible to the infection by trematode cercariae than the fish from the uncontaminated lake. The roach collected from contaminated and uncontaminated lakes were infected experimentally by Rhipidocotyle fennica cercariae. The experiments were conducted also to determine the effects of a mass penetration of cercariae through the fins and skin of roach. For this purpose certain physiological parameters were selected to determine the condition of roach during the infection. To characterise these changes clinical diagnostic parameters were used, established earlier for the common carp (Jeney and Jeney 1987). Parameters were assembled in such a way that they would characterise the nonspecific stress response (leukocrit values), general condition of the fish (haematocrit, total protein and calcium and chloride concentrations) and the specific changes (activities of transaminases and alkaline phosphatase). The interaction of pollution, parasites and fish, 
especially physiological changes in the host are poorly known, although a majority of fish are always parasitised with some parasite species and anthropogenic changes can be very common in some areas of water bodies.

\section{MATERIALS AND METHODS}

Study area. Fish for the experiments were caught from two lakes: Lake Vatia, which is contaminated by pulp and paper mill effluents, and an oligotrophic and unpolluted Lake Peu-runka. The lakes are in hydraulic continuity but the connecting river is dammed, preventing fish migration from Lake Vatia upstream to Lake Peurunka. For the history of the pollution of Lake Vatia and the description of study area in more detail see Valtonen et al. (1997). Briefly: chlorine was used for bleach-ing pulp in pulp and paper mills at Äänekoski, $15 \mathrm{~km}$ north of Lake Vatia, from 1956 up to 1991. Active sludge treatment of effluents started in 1985 and had significantly decreased the biological oxygen demand loading of the recipient water bodies. In 1991 the mill stopped using elementary chlorine for bleaching. Lake Peurunka is larger than Lake Vatia, which is more a river-like lake with a water retention time of 3-4 days, compared to 3.4 years in Peurunka.

Experimental design. Adult roach were gill netted in midJuly 1990 from each of the study lakes and were transported to the laboratory. The two groups of fish were placed separately into two 200-1 aquaria in aerated tap water in order to prevent the effect of differential water quality on the emerging cercariae. Water in the aquaria was changed every third day. Water quality parameters were: temperature 17$19^{\circ} \mathrm{C}$, oxygen $8-9 \mathrm{mg} / 1, \mathrm{pH} 7.8-8.1, \mathrm{NH}_{4}-\mathrm{N} 2.4-3.1 \mathrm{mg} / 1$ and total $\mathrm{N} 1.9-2.4 \mathrm{mg} / \mathrm{l}$. Roach were acclimatised to the experimental conditions for $72 \mathrm{~h}$ before infection by Rhipidocotyle fennica cercariae. A group of fish from each lake were kept in separate aquaria as uninfected controls $(\mathrm{n}=$ 8 from unpolluted lake, $\mathrm{n}=8$ from polluted lake) and were sampled prior to the infection and at the end of the experiment on day 10 post infection (p.i.). The infection was carried out using cercariae-producing clams (Anodonta piscinalis), which were collected 2 months earlier from a nearby lake: 11 randomly chosen cercariae-producing molluscs were introduced into each aquarium with fish $(\mathrm{n}=15$ from unpolluted lake, $\mathrm{n}=15$ from polluted lake) at 18:00 and removed at 14:00 the next day. The clams were changed once between the aquaria to make the exposure of fish to emerging cercariae identical in both aquaria. Infected clams produce cercariae all day, maximum release occurring between 08:00 and 10:00 (Taskinen et al. 1991). Fish were sampled on days 1,2 and 10 after the exposure to cercariae.

Sampling procedure. Fish were stunned by a blow to the head, weighed quickly, and blood samples were collected from the caudal vessel by means of heparinised syringe and needle. Blood samples were kept on ice and centrifuged promptly after collection. Parasites were then counted by excising the fins and examining them on glass plates, using transmitted light and $\times 10-40$ magnification (Taskinen et al. 1991).

Analytical procedures. For determination of haematocrit and leukocrit values, blood was collected in heparinised microcapillary tubes and centrifuged. Haematocrit was expressed as a percentage of total blood volume. Leukocrit was determined microscopically as a percentage of leukocytes in total blood volume. Blood was centrifuged at 2,000 $\times \mathrm{g}$ for $10 \mathrm{~min}$. Plasma was separated and stored at $-20^{\circ} \mathrm{C}$. Plasma calcium and chloride concentrations were determined by colorimetric method (Galenopharm, Switzerland). Total protein content was measured by biuret method. The activities of transaminases (GOT and GPT) were investigated colorimetrically (Boehringer, Germany). Alkaline phosphatase activity was determined by a colorimetric method (Merck, Germany).

Statistical analysis. Two-way multivariate analysis of variance (MANOVA) was done to study the influence of pollution level and the infection (=treatment) on physiological parameters of roach. Due to earlier findings and knowledge on the effects of pollution on the physiology and immune parameters of fish, in the present experiment, the pollution level (=lake) was handled as a block treatment of two-way MANOVA.

\section{RESULTS}

All fish exposed to cercariae were successfully infected with Rhipidocotyle fennica. Infection (including time) and also the pollution level, had a significant influence on physiological parameters measured (Table 1). Intensity of infection increased during the experiment and roach from the contaminated lake showed a significantly higher mean abundance after 1 and 2 days p.i. than fish originating from the uncontaminated lake. However, there was no difference between the two groups on day 10 p.i. No parasites were found in the control fish (Fig. 1). Leukocrit values, both in the infected and non-infected fish, were significantly lower in fish originating from the contaminated lake. Infection was associated with significantly decreased leukocrit values as compared to the non-infected control group (Fig. 1, Table 2). Plasma protein concentrations were higher in control fish at the onset and at the end of experiment, and also in infected roach from the uncontaminated lake but the differences were not significant (Tables 2, 3). Significant increase in the activity of plasma transaminases (GOT and GPT) was observed in both infected groups in relation to time, with the clear peak values on day 2 p.i. (Fig. 2, Table 2). Significantly higher plasma alkaline phosphatase activities were observed, especially on day 1 p.i., in roach from the contaminated lake compared to those from the uncontaminated lake but there was no relation to the infection time (Fig. 2, Table 2). No clear changes were found in haematocrit, although some lower values were noted on day 2 p.i. in fish from the contaminated lake (Table 3). No significant differences in plasma calcium and chloride concentrations were noted in relation to time, but between the fish from the uncontaminated and the contaminated lakes plasma $\mathrm{Cl}-$ ions had higher values in fish from contaminated lake except on day 10 p.i. (Tables 2, 3). 
Table 1. The influence of experimental Rhipidocotyle fennica cercariae exposure on the physiological parameters of roach (Rutilus rutilus) caught from a BKME-polluted and an unpolluted lake in Central Finland. The results are from a block experiment (two-way MANOVA) where the block treatment is pollution level (lake) and the experimental treatment is time of infection. Response variables are the physiological parameters in the plasma: haematocrit, leukocrit, total protein, calcium and chloride concentration and the activity of GOT, GPT and alkaline phosphatase.

\begin{tabular}{|l|c|c|c|c|}
\hline Effect & Wilk's $\lambda$ & F-statistics & $\mathrm{df}$ & $\mathrm{p}$ \\
\hline $\begin{array}{l}\text { Block } \\
\text { (pollution level) } \\
\text { Treatment } \\
\text { (infection time) }\end{array}$ & 0.35 & 5.16 & 8,22 & 0.001 \\
$\begin{array}{l}\text { Interaction } \\
\text { (block * treatment) }\end{array}$ & 0.34 & 0.88 & 32,82 & 0.649 \\
\hline
\end{tabular}

Table 2. The influence of experimental Rhipidocotyle fennica cercariae exposure on the physiological parameters of roach (Rutilus rutilus) caught from a BKME-polluted and an unpolluted lake in Central Finland. ANOVA results advised by MANOVA process (see Table 1).

\begin{tabular}{|l|c|c|c|c|c|c|}
\hline \multirow{2}{*}{ Response variable } & \multicolumn{2}{|c|}{$\begin{array}{c}\text { Block } \\
(\mathrm{df} 1,29)\end{array}$} & \multicolumn{2}{c|}{$\begin{array}{c}\text { Treatment } \\
(\mathrm{df} 32,82)\end{array}$} & \multicolumn{2}{c|}{$\begin{array}{c}\text { Interaction } \\
(\mathrm{df} 32,82)\end{array}$} \\
& $\mathrm{F}$ & $\mathrm{p}$ & $\mathrm{F}$ & $\mathrm{p}$ & $\mathrm{F}$ & $\mathrm{p}$ \\
\hline Haematocrit & 0.13 & 0.72 & 1.42 & 0.25 & 1.85 & 0.15 \\
Leukocrit & 8.41 & 0.01 & 3.51 & 0.02 & 0.33 & 0.85 \\
GOT & 1.38 & 0.25 & 22.00 & $<0.001$ & 0.36 & 0.83 \\
GPT & 0.21 & 0.65 & 15.90 & $<0.001$ & 1.28 & 0.30 \\
Alkaline phosphatase & 6.35 & 0.02 & 0.09 & 0.98 & 0.44 & 0.78 \\
Protein & 2.08 & 0.16 & 1.68 & 0.18 & 0.60 & 0.67 \\
Calcium & 1.18 & 0.29 & 0.35 & 0.84 & 0.48 & 0.75 \\
Chloride & 4.39 & 0.04 & 1.37 & 0.27 & 0.27 & 0.89 \\
\hline
\end{tabular}

Table 3. Changes in haematocrit levels, total protein, calcium and chloride concentrations in the plasma of roach from unpolluted and polluted lakes due to experimental infection by Rhipidocotyle fennica. The results are expressed as the mean \pm standard deviation.

\begin{tabular}{|c|c|c|c|c|}
\hline Group & $\begin{array}{c}\text { Haematocrit } \\
\%\end{array}$ & $\begin{array}{c}\text { Plasma protein } \\
\mathrm{mg} / \mathrm{ml}\end{array}$ & $\begin{array}{c}\mathrm{Ca} \\
\mathrm{mmol} / 1\end{array}$ & $\begin{array}{c}\mathrm{Cl} \\
\mathrm{mmol} / 1\end{array}$ \\
\hline \multirow{2}{*}{\multicolumn{5}{|c|}{$\begin{array}{l}\text { Control, day } 0 \\
\text { unpolluted }(n=4)\end{array}$}} \\
\hline & $32.2 \pm 3.5$ & $36.7 \pm 8.7$ & $2.27 \pm 0.37$ & $57.7 \pm 15.1$ \\
\hline & $34.0 \pm 5.6$ & $38.1 \pm 4.1$ & $2.54 \pm 0.38$ & $67.4 \pm 7.2$ \\
\hline \multicolumn{5}{|l|}{ Infected, day 1 p.i. } \\
\hline unpolluted $(\mathrm{n}=5)$ & $33.8 \pm 7.1$ & $33.9 \pm 5.4$ & $2.68 \pm 0.60$ & $52.0 \pm 15.8$ \\
\hline polluted $(\mathrm{n}=5)$ & $30.8 \pm 3.8$ & $28.6 \pm 9.0$ & $2.24 \pm 0.30$ & $59.6 \pm 23.9$ \\
\hline \multicolumn{5}{|l|}{ Infected, day 2 p.i. } \\
\hline unpolluted $(\mathrm{n}=5)$ & $34.6 \pm 4.6$ & $30.3 \pm 10.0$ & $2.30 \pm 0.55$ & $49.2 \pm 16.2$ \\
\hline polluted $(\mathrm{n}=5)$ & $25.6 \pm 10.2$ & $29.2 \pm 4.9$ & $2.14 \pm 0.53$ & $66.0 \pm 6.5$ \\
\hline \multicolumn{5}{|l|}{ Infected, day 10 p.i. } \\
\hline unpolluted $(\mathrm{n}=5)$ & $29.1 \pm 4.7$ & $33.7 \pm 4.7$ & $2.44 \pm 0.43$ & $72.1 \pm 11.5$ \\
\hline polluted $(\mathrm{n}=5)$ & $30.0 \pm 2.5$ & $25.5 \pm 9.5$ & $2.08 \pm 0.12$ & $70.1 \pm 3.1$ \\
\hline \multicolumn{5}{|l|}{ Control, day 10} \\
\hline unpolluted $(\mathrm{n}=4)$ & $21.7 \pm 5.1$ & $36.3 \pm 9.9$ & $2.54 \pm 0.51$ & $60.2 \pm 11.5$ \\
\hline polluted $(\mathrm{n}=4)$ & $28.7 \pm 1.0$ & $33.3 \pm 4.4$ & $2.39 \pm 0.90$ & $72.2 \pm 18.4$ \\
\hline
\end{tabular}

\section{DISCUSSION}

Our present study reveals that roach originating from Lake Vatia contaminated with BKME were more susceptible to penetration by Rhipidocotyle fennica cercariae during the first two days after exposure than the fish from uncontaminated Lake Peurunka. This is in accordance with an earlier finding demonstrating that the immune functions are impaired in roach originating from the contaminated Lake Vatia (Jokinen et al. 1995). In previous studies from the same area, a similar explanation was suggested for the increase of the ciliate, Ichthyophthirius multifiliis, infection (Valtonen and Koskivaara 1994) and the increase in Dactylogyrus species communities (Koskivaara et al. 1991) in roach from contaminated Lake Vatia. Moreover, Barker et al. (1994) reported that the prevalence and intensity of metacercariae of Cryptocotyle lingua on the fins and 

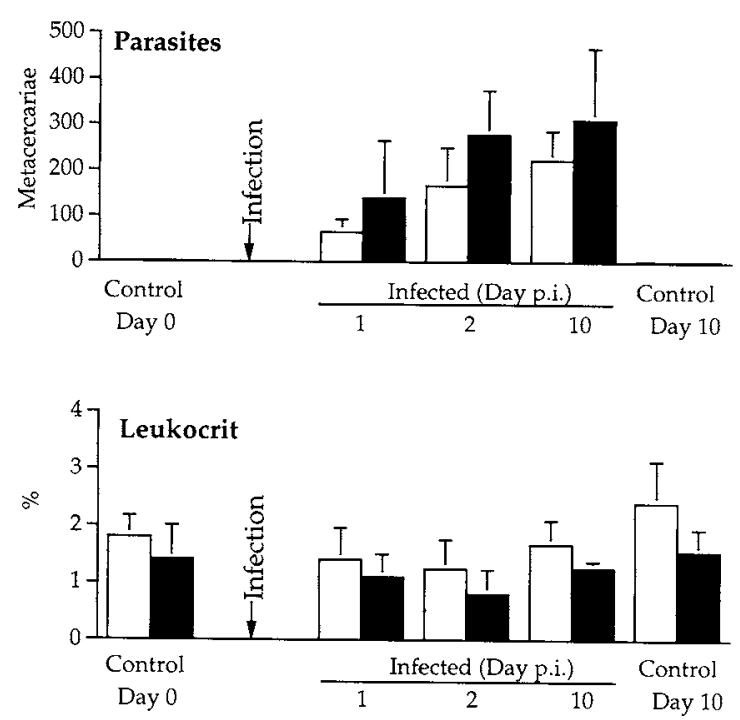

Fig. 1. Effect of experimental infection by Rhipidocotyle fennica. Mean abundance of metacercariae and leukocrit levels in roach originating from the unpolluted (white bars) and the polluted lake (black bars). Results are expressed as the mean + standard deviation.
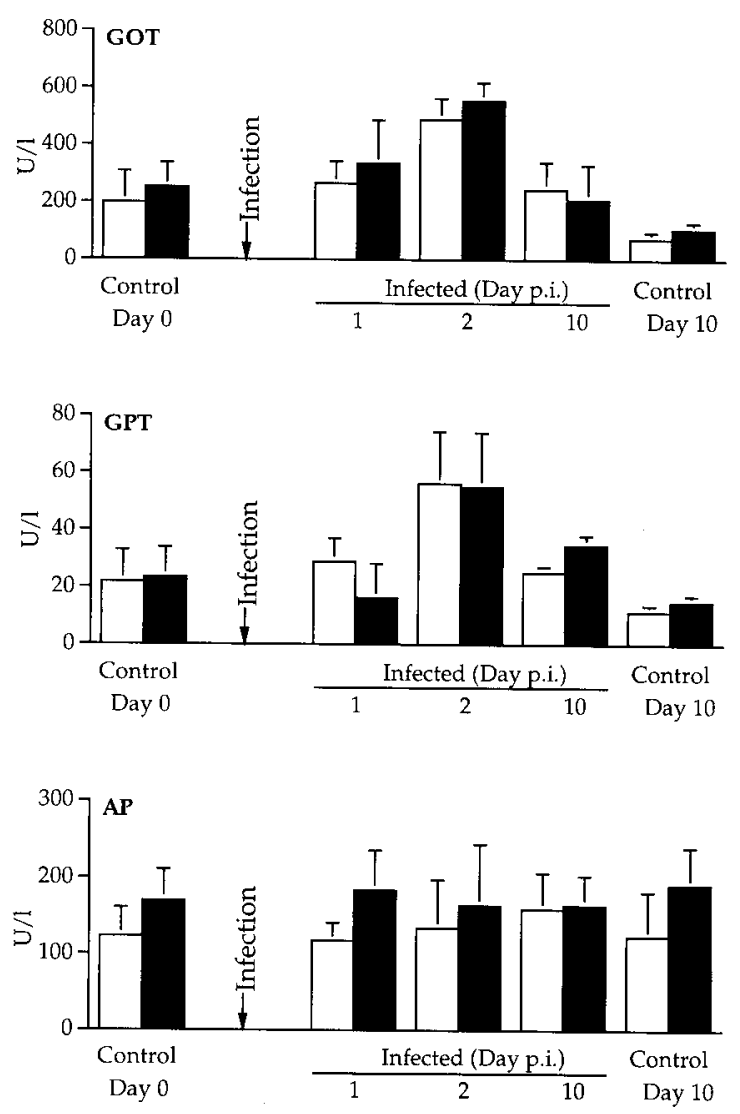

Fig. 2. Effect of experimental infection by Rhipidocotyle fennica on plasma transaminases (GOT and GPT) and alkaline phosphatase (AP) activities in roach originating from the unpolluted (white bars) and the polluted lake (black bars). Results are expressed as the mean + standard deviation. gills of winter flounder (Pleuronectes americanus) in waters adjacent to a pulp and paper mill were higher than in the clean reference area.

Other studies have shown that increased prevalence of protozoan ciliates is a sensitive indicator of several pollutants (Khan and Thulin 1991), and this was also shown experimentally by Lehtinen (1989). Both increases and decreases in the prevalence of ectoparasitic monogeneans have been noted in fish exposed to various pollutants (Khan and Thulin 1991). In the present study area, we have shown experimentally an increase in Dactylogyrus species in the contaminated lake (Bagge and Valtonen 1996), but a decrease in the abundance of Dactylogyrus species communities when the BKME concentration was increased above that found in the lake (Siddal et al. 1996). It seems, therefore, that the effluents influence the parasite communities both through the immunological response and condition of the host, although both affect also the parasites themselves. To avoid the influence of water quality on the emerging cercariae the infection in the presents study was done in clean aerated tap water, not in the water of each lake.

Infected clams in the present study were collected from a single, nearby lake to eliminate potential effect of different host races on the infectivity of the cercariae caused by host-parasite co-evolution. Lively (1989) reported, using cross infections, that cercariae-infected hosts from their own location were more readily infected than hosts from another site. In our study, infection of the clam, Anodonta piscinalis, with $R$. fennica was confirmed beforehand and the cercariaeproducing molluscs were divided randomly between the two tanks. Finally the change of molluscs between the two aquaria during the exposure ensured homogeneous infection. The difference in the mean abundance of $R$. fennica infections could also be due to genetic differences be-tween the two populations of roach (Lively 1989). This is unlikely, however, since fish in this area were able to migrate between the lakes until the connecting river was dammed in the 1960s.

Rhipidocotyle fennica cercariae live freely for only 24 hours and are infective to the roach (second intermediate host) for a short period of time. After one day p.i., no new cercariae penetrate the roach (Taskinen et al. 1991). The abundance of the infection, however, increased even after that time. This occurred because newly penetrated cercariae were very transparent and difficult to see but they are easier to detect after two days. This could also explain the increase in mean abundance on day 10 p.i. - the colouration of the cysts had occurred and all parasites were clearly visible.

Stress caused by the attack of huge numbers of penetrating cercariae was observed in the decrease of leukocrit values in both fish groups, and the values were always lower in fish originating from the contaminated lake. In another of our studies, after exposure to raw BKME for three days, the leukocrit value of roach caught from a lake contaminated by BKME decreased 
more than that of the fish from an uncontaminated lake (Jeney et al. 1996). In addition, leukocrit values decreased when roach from the uncontaminated site were caged in the contaminated lake for three weeks. Decreased leukocrit values support the previous data on a connection between the increased parasitic protozoan and monogenean infections and impaired immunological response of roach in Lake Vatia polluted by BKME (Valtonen and Koskivaara 1994, Jokinen et al. 1995).

In the present study, there was no difference in haematocrit between either groups. Haemoglobin values might have been a better parameter for estimation of stressed condition. However, Khan (1987) could not find any decrease in haematocrit or haemoglobin in oiltreated and parasitised cods. On the other hand, Lehtinen et al. (1990) found a significant reduction in number of red blood cells in trout exposed to 400 and 2000 times diluted effluent from conventional chlorine bleaching.

The real destructive effect of penetrating $R$. fennica cercariae on tissues of roach is seen most clearly in the peak values of plasma transaminase enzymes two days p.i. These enzymes are released into the plasma of fish only when tissues are damaged (Nemcsok et al. 1981, Jeney et al. 1984). Fish originating from the polluted lake had a slightly higher GOT activity during the two days p.i. The higher levels of alkaline phosphatase in the blood of roach from the contaminated lake in both infected and control fish indicated that the liver of the fish was affected (Ozretic and Krajnovicozretic 1993). It was interesting to note that, on the first two days after infection, the activity of alkaline phosphatase in the fish from the contaminated lake increased, although not significantly, whereas in the fish from the uncontaminated lake the activity did not increase. The recovery of the enzyme activity to pre-injection levels on day 10 p.i. confirms that, at this stage of infection, parasites are encysted and the wounds caused by penetration have been healed.

The slight but not significant decrease in plasma protein in both groups after the infection may be due to the penetration of parasites. Low levels of plasma total protein possibly have significance in the cases of infectious disease, kidney damage, and nutritional imbalance of fish, while high values may reflect haemoconcentration or impaired water balance in stressed fish (Wedemeyer and McLeay 1981). In the infected fish originating from the contaminated lake, the protein content remained decreased up to the end of the experiment, which implies that the fish were still affected by the infection.

Calcium and chloride concentrations generally decrease in cyprinids following exposure to different stressors (Jeney and Jeney 1995). We found increased chloride values in the roach from the contaminated lake both in the infected and control fish although in our previous experiments roach kept in the contaminated and uncontaminated lakes for three weeks did not differ significantly (Jeney et al. 1996). Oikari et al. (1985) also reported that the concentration of plasma chloride in rainbow trout did not exhibit significant changes after 21 days after exposure to BKME.

Our results suggest that roach from polluted lake suffer from a general stress syndrome following penetration of digenean cercariae. The success of a parasite often depends on the state of health and resistance of the host. Chronic stress can lead to elevation of the cortisol level in the blood, with resultant suppression of the immune system, and thus to an increased likelihood of diseases and parasitic infestation (Lehtinen et al. 1984, Pickering and Pottinger 1989).

The results of the present study demonstrate that the roach originating from contaminated lake reacted ineffectively in the experimental exposure with parasite. Penetrating cercariae caused more injury in the fish from the contaminated lake than in the fish from the uncon-taminated lake, and this was manifested in lower levels of leukocrit as well as higher levels of plasma GOT and GPT. Alkaline phosphatase did not change in relation to infection although higher activities were detected in the roach from the contaminated lake.

Acknowledgements. Research grants given by the European Science Foundation (Research Program in Toxicology) to Z. Jeney, as well as the Hungarian-Finnish Scientific and Technical Co-operation (implemented by Hungarian OMFB and Finish CIMO) are acknowledged. The present study was funded also by the Research Council for the Environmental Board of the Academy of Finland. The authors would like to thank Dr. J. Taskinen for his technical assistance during experimental work and Mr. M. Julkunen, MSc. for help with statistics. Dr. W. Yeomans has kindly checked the English.

\section{REFERENCES}

BAGGE A.M., VALTONEN E.T. 1996: Experimental study on the influence of water pollution on the gill parasite communities of roach (Rutilus rutilus). Parasitology 112: 499-508.

BARKER D.E., KHAN R.A., HOOPER R. 1994: Bioindicators of stress in winter flounder, Pleuronectes americanus, captured adjacent to a pulp and paper mill in St. George's Bay, Newfoundland. Can. J. Fish. Aquat. Sci. 51: 22032209.
GRANBERG K.E. 1992: Changes in water quality in Lake Päijänne following decrease of effluent load from the pulp and paper industry in 1969-1989. Hydrobiologia 243/244: 395-403.

JENEY Z., JENEY G. 1987: A system of diagnostic parameters for detection of environmental impact on fish. Abstracts 3rd Int. Conf. Eur. Assoc. Fish Pathol., Bergen, Norway, p. 46. 
JENEY Z., JENEY G. 1995: Recent achievements in studies of diseases of common carp (Cyprinus carpio L.). Aquaculture 129: 397-420.

JENEY G., NEMCSOK J., OLÁH J. 1984: Transaminase enzyme activity of cyprinid fishes depending on environmental factors and bacterial infection. Symp. Biol. Hung. 23: 201-207.

JENEY Z., VALTONEN E.T., JENEY G., JOKINEN E.I. 1996: Effects of pulp and paper mill effluent (BKME) on physiology and biochemistry of the roach (Rutilus rutilus L.). Arch. Environm. Contam. Toxicol. 30: 523-529.

JOKINEN E.I., AALTONEN T.M., VALTONEN E.T. 1995: Subchronic effects of pulp and paper mill effluents on the immunoglobulin synthesis of roach, Rutilus rutilus. Ecotoxicol. Environ. Saf. 32: 219-225.

KHAN R.A. 1987: Effects of chronic exposure to petroleum hydrocarbons of two species of marine fish infected with a hemoprotozoan, Trypanosoma murmanensis. Can. J. Zool. 65: 2703-2709.

KHAN R.A., THULIN J. 1991: Influence of pollution on parasites of aquatic animals. Adv. Parasitol. 30: 201-238.

KOSKIVAARA M., VALTONEN E.T., PROST M. 1991: Dactylogyrids on the gills of roach in Central Finland: features of infection and species composition. Int. J. Parasitol. 21: 565-572.

LEHTINEN K.J. 1989: Survival, growth and disease of threespined stickleback, Gasterosteus aculeatus L., brood exposed to bleaching kraft mill effluents (BKME) in mesocosms. Ann. Zool. Fenn. 26: 133-143.

LEHTINEN K.J., KIERKIRGAARD A., JAKOBSON E., WAENDELL A. 1990: Physiological effects in fish exposed to effluents from mills with six different bleaching processes. Ecotoxicol. Environ. Saf. 19: 433-436.

LEHTINEN K.J., NOTINI M., LANDLER L. 1984: Tissue damage and parasite frequency in flounder Platichthys flesus chronically exposed to bleached kraft pulp mill effluents. Ann. Zool. Fenn. 21: 23-28.

LIVELY G.M. 1989: Adaptation by a parasite trematode to local populations of its snail host. Evolution 43: 16631671.

NEMCSOK J., BENEDECZKY I., BOROSS L., ASZTALOS B., ORBAN L. 1981: Subcellular localisation of transaminase enzymes in fishes and their significance in the detection of water pollution. Acta Biol. Szeged. 27: 9-15.

OIKARI A., HOLMBOM B. 1986: Assessment of water contamination by chlorophenolics and resin acids with the aid of fish bile metabolites. Aquat. Toxicol. Environ. Fate ASTM STP 921, 9: 252-267.

OIKARI A., HOLMBOM B., ÅNÄS E., MIILUNPALO M., KRUZYNSKI G., CASTREN M. 1985: Ecotoxicological aspects of pulp and paper mill effluents discharged to an inland water system: distribution in water, toxicant residues and physiological effects in caged fish (Salmo gairdneri). Aquat. Toxicol. 6: 219-239.

OZRETIC B., KRAJNOVICOZRETIC M. 1993: Plasma sorbitol dehydrogenase, glutamate dehydrogenase, and alkaline phosphatase as potential indicators of liver intoxication in grey mullet (Mugil auratus Risso). Bull. Environ. Contamin. Toxicol. 50: 586-592.

PAJULA H., MATINVESI J. 1984: Puiden pudotustoiminnan aiheuttama välitön vesistökuormitus. Esimerkkialueina Pajulahden ja Akonpohjan pudotuspaikat. Vesihallituksen monistesarja 267: 1-47.

PICKERING A.D., POTTINGER T.G. 1989: Stress responses and disease resistance in salmonid fish: effects of chronic elevation of plasma cortisol levels. Fish Physiol. Biochem. 7: 253-258.

SIDDAL R., KOSKIVAARA M., VALTONEN E.T. 1996: Dactylogyrus spp. (Monogenea) infections on the gills of roach (Rutilus rutilus L.) experimentally exposed to paper and pulp mill effluents. Parasitology 114: 439-446.

TANA J., LEHTINEN K.J. 1996: The aquatic environmental impact of pulping and bleaching operations - an overview. Finnish Environment Institute Report 17, Helsinki, Finland, pp. 103.

TASKINEN J., VALTONEN E.T., GIBSON D.I. 1991: Studies on bucephalid digeneans parasitising molluscs and fishes in Finland. 1. Ecological data and experimental studies. Syst. Parasitol. 19: 81-94.

VALTONEN E.T., HOLMES J.C., KOSKIVAARA M. 1997: Eutrophication, pollution and fragmentation: effects on the parasite communities in roach (Rutilus rutilus) and perch (Perca fluviatilis) in four lakes in Central Finland. Can. J. Fish. Aquat. Sci. 54: 572-585.

VALTONEN E.T., KOSKIVAARA M. 1994: Relationships between the parasites of some wild and cultured fishes in two lakes and a fish farm in Central Finland. Int. J. Parasitol. 24: 109-118.

WEDEMEYER G.A., McLEAY D.J. 1981: Methods for determining the tolerance of fishes to environmental stress. In: A.D. Pickering (Ed.), Stress and Fish. Academic Press, London, pp. 247-268. 